Limnol. Rev. (2016) 16, 4: 173-183

DOI 10.1515/limre-2016-0019

\title{
Comparative studies of underwater light regimes in lakes of the East-Suwałki Lakeland
}

\author{
Dariusz Borowiak $^{1,2}$, Magdalena Borowiak ${ }^{1}$ \\ ${ }^{1}$ Department of Limnology, University of Gdańsk, Bażyńskiego 4, 80-952 Gdańsk, Poland, e-mail: geodb@univ.gda.pl (corresponding \\ author),geomb@univ.gda.pl \\ ${ }^{2}$ Limnological Station in Borucino, University of Gdańsk, 83-323 Kamienica Szlachecka, Poland, e-mail: geodb@univ.gda.pl
}

\begin{abstract}
Secchi disc transparency and optical properties of water, based on measurements for downward irradiance using an underwater radiometer PER-700, were studied in 23 lakes of the Suwałki Landscape Park (SLP) in 2013. Measurements of optically significant constituents of water were also performed (YSI EXO-2) and analysed. Data on water transparency from published studies were used to assess long-term changes in the optical conditions in the deepest water body in Poland - Lake Hańcza. In terms of the optical characteristics of the water, the analysed SLP lakes can essentially be divided into two distinct groups representing different optical lake types. These are optical categories of lakes most common in Poland, namely types II and IIIb. Regional equations describing the relationships between the attenuation coefficient for downward irradiance as well as optically significant constituents of water were developed. The optical properties of the SLP lakes are mainly affected by suspended solids, mostly phytoplankton. Interannual fluctuations in Sechi disc transparency, as well as the attenuation coefficient for downward irradiance and other apparent optical properties of mid-summer water calculated from it, are determined by the spring thermal conditions and intensity of phytoplankton blooms during this period. Application of the attenuation coefficient for downward irradiance as a criterion for the assessment of the trophic status of the SLP lakes indicates that these are generally eutrophic lakes. The largest and deepest lakes of the park, however, are mesotrophic. Lake Hańcza is currently in the stage of $\alpha$-mesotrophy.
\end{abstract}

Key words: Secchi disc transparency, vertical attenuation coefficient, euphotic zone depth, optical classification of inland waters, trophic state

\section{Introduction}

Overall abiotic conditions of lacustrine ecosystems are shaped by a combination of physical-limnological factors reflecting both current and past relationships linking the lake with its surroundings (Lange 1986). Features of the abiotic environment of lakes define the external conditions of the functioning of certain biocoenoses, while at the same time being subject to changes caused by them. The final state of the ecosystem, as well as its properties, are a direct consequence of the exchange of energy and matter with the environment and the internal bio-geo-chemical transformations occurring in the lake.

Solar energy is the main factor determining the dynamics of lacustrine ecosystems. It is involved in processes important for the ecosystem functioning, such as heating and lighting water, photosynthesis and primary production of organic matter, as well as being a source of energy for most biochemical reactions. The amount of light energy penetrating the lake to a specific depth depends on the optical properties of the water. These in turn are formed by admixtures of water, known as optically significant constituents (OSC). Besides the water, there are mainly suspended substances (phytoplankton, organic and mineral tripton), as well as coloured dissolved substances (humic substances). The variability of concentrations of these admixtures affect the amount of transmitted light in the water and its spectral composition within the water body. In natural waters, these substances are present in different configurations of concentration, so the variation of the optical properties of lake waters can be very highly diverse. This diversity is observed not only between lakes situated in different climatic and geographical zones, but also in water bodies found in the same geographical area or region.

Hydro-optical studies of the Suwałki region lakes already have a long tradition. The first studies were undertaken in the interwar period (Koźmiński 1932; Stangenberg 1936, 1937), and were contin- 
ued in the following years (Stenz and Mikulski 1951; Szczepański 1961, Mikulski 1973; Lange et al. 2003; Górniak et al. 2007; Zdanowski et al. 2008; Ficek 2013; Borowiak 2014). These studies relate primarily to the measurements of Secchi disc transparency. As the measurements of light transmission in the water based on the use of underwater actinometers, quantum meters, and radiometers were sporadic, they do not give rise to an overall assessment of the optical conditions of this group of lakes.

The main objective of this study was to attain a comprehensive knowledge of the optical properties of lake waters in the Suwałki Landscape Park (SLP), based on radiometric measurements and traditional Secchi disc transparency measurements. The adopted complementary aims were as follows: (i) to assess natural conditions of optical diversity of lake water, (ii) analyse regional relationships between optical properties and optically significant constituents of the water, (iii) specify the hydro-optical types of lakes and their trophic status, and (iv) determine trends in the changes of the optical conditions actually occurring in the lakes.

\section{Research area and methods}

The East-Suwałki Lakeland is a geographical mesoregion located in north-eastern Poland near the border with Russia (Kaliningrad region) and Lithuania. Within Poland the region covers an area of about $1250 \mathrm{~km}^{2}$ (Kondracki 1994). The morphology of the region is genetically determined by accumulation and erosion of the Vistulian ice-sheet. The main landforms in this area are hilly and undulating moraine plateaus cut by deep erosion forms (subglacial channels) and depressions formed from melt-out blocks of dead ice. These depressions often contain lakes, whose total number is 167 . The hydro-optical study included 23 lakes located in the northern part of the region within the Suwałki Landscape Park (SLP) (Fig. 1). It is the most elevated area of the East-Suwałki Lakeland;

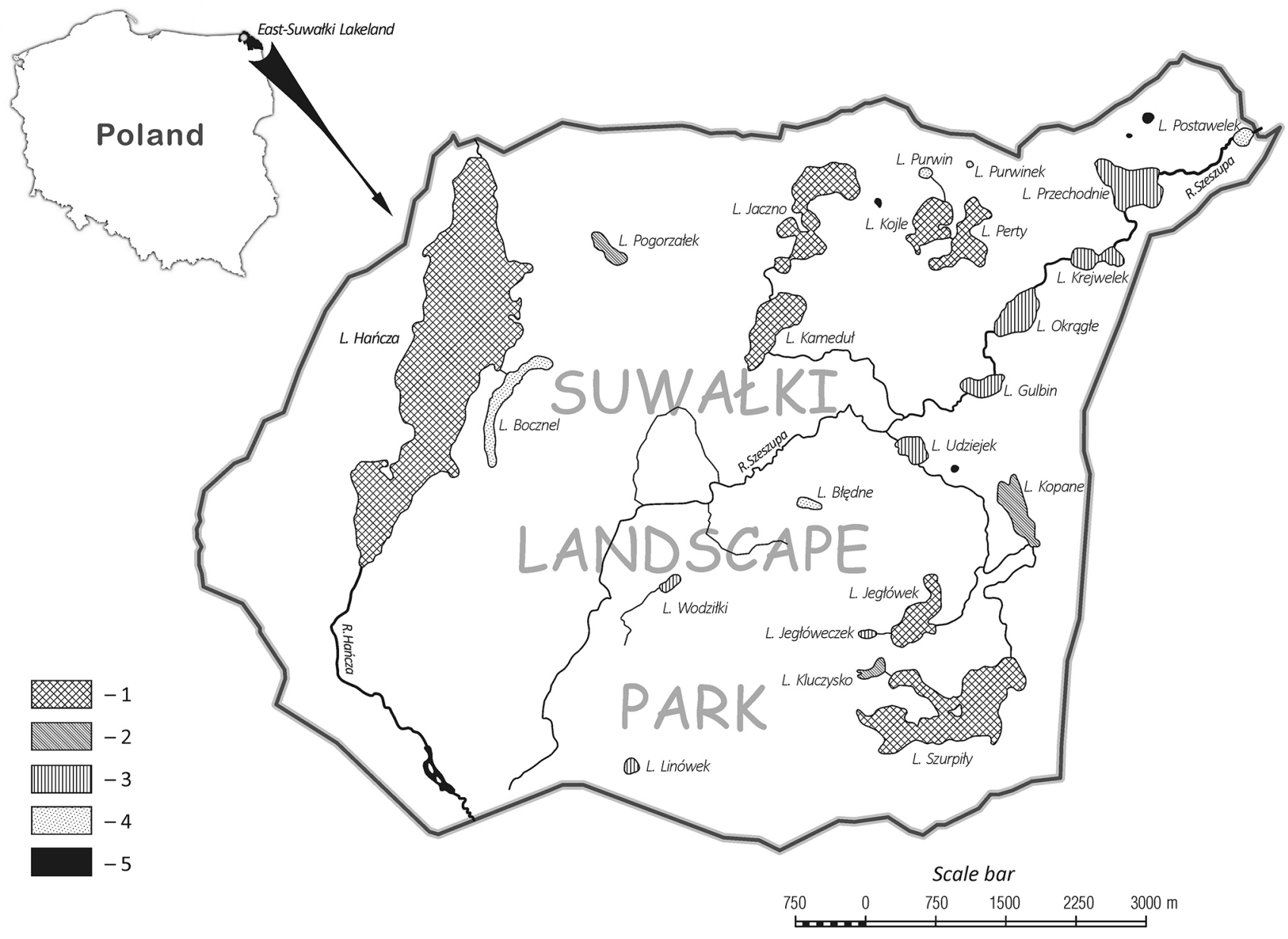

Fig. 1. Distribution of studied lakes within the Suwałki Landscape Park. Explanation: 1 - very deep lakes, 2 - deep lakes, 3 - medium deep lakes, 4 - shallow lakes, 5 - other water bodies (unstudied) 
it reaches almost $300 \mathrm{~m}$ a.s.l., and the denivelations commonly exceed $50 \mathrm{~m}$. In the surface deposits glacial till prevails. Smaller areas are covered by deposits of fluvioglacial accumulation (sands, gravels, silts) and the ice-marginal lacustrine accumulation (clays, silts) (Richling 1985).

All the studied lakes have glacial origins. These are mainly kettle lakes filling up the depressions between forms of crevasse accumulation (e.g. Jaczno, Perty, Kojle). Channel lakes include the deepest lake, not only in the region but also in Poland - Lake Hańcza. Examples of ground moraine lakes include Lakes Szurpiły (moraine-ice-dammed), as well as Bocznel, Linówek, Kopane (intermoraine). The morphometry of the lakes is varied. Maximum depths range from 3.3 (Purwinek) to $105.6 \mathrm{~m}$ (Hańcza). Most of the lakes are medium deep (8 lakes) and very deep (7). There are five shallow lakes and three deep lakes (Fig. 1). In terms of area and volume, the lakes differ by, respectively, 3 and 4 orders of magnitude (Table 1 ).

The basic measurement data were collected in August 2013, during the maximum development of the vertical stratification of environmental characteristics (summer stagnation). Measurements in the water column directly above its deepest part provide data that are not only representative of a particular lake but also allow comparsons to be made with other lakes. The measurements carried out at such sites included water temperature, concentrations of chlorophyll- $a$, turbidity (multi-parameter probe YSI EXO2) and downward irradiance (radiometer PER-700). The water quality features were recorded from the surface to the bottom at one-meter intervals. The scope of optical studies included measurement of photosynthetically active radiation $(P A R)$, and monochromatic light with a wavelength of 380, 443, 490, 565, 670 and $780 \mathrm{~nm}$. Measurements for downward irradiance $\left(E_{d}\right)$ were performed continuously from the surface to a depth at which the irradiance was still great enough for the correctness of the reading to remain unaffected by the level of the noise. The results of the optical measurements were used to calculate the spectral diffuse attenuation coefficients for downward irradiance $\left(K_{d}(\lambda)\right)$, and for photosynthetically active radiation $\left(K_{d, P A R}\right)$. The mean attenuation coefficients $\left(\bar{K}_{d}\right)$ were determined from the slope of the linear regression of the natural logarithm of downward irradiance $\left(E_{d}\right)$ versus depth $(z)$ (Morris et al. 1995). For each lake additional optical characteristics of lake waters, derivative with respect to the attenuation coefficient, such as euphotic zone range $\left(z_{\text {eu }}\right)$, mean transmittance $(\bar{T})$ and mean epilimnion irradiance $\left(\bar{E}_{\text {mix }}\right)$ were calculated. These characteristics are among the so-called apparent optical properties of the aqueous medium.

In limnological practice, the euphotic zone depth $\left(z_{e u}\right)$ is defined as the depth where $1 \%$ of the immediate

Table 1. Morphometric and surface water quality features of the Suwałki Landscape Park lakes. Explanation: $A_{0}$ - water surface area; $V-$ volume; $z_{\max }$ - maximum depth; $\bar{z}$ - mean depth; Chl- $a$ - chlorophyll- $a$ concentration; TUR - turbidity; TC - true water colour

\begin{tabular}{|c|c|c|c|c|c|c|c|c|}
\hline Lake & $A_{0}\left[\mathrm{hm}^{2}\right]$ & $V\left[\mathrm{dam}^{3}\right]$ & $z_{\text {max }}[\mathrm{m}]$ & $\bar{z}[\mathrm{~m}]$ & Chl-a $\left[\mu \mathrm{g} \mathrm{dm}^{-3}\right]$ & TUR [NTU] & $T C\left[\mathrm{mg} \mathrm{Pt} \mathrm{dm}^{-3}\right]$ & TUR/TC \\
\hline Błędne & 2.74 & 52.6 & 4.8 & 1.9 & 27.7 & 6.2 & 18.1 & 0.34 \\
\hline Bocznel & 19.17 & 243.2 & 3.9 & 1.3 & 10.4 & 6.4 & 14.5 & 0.44 \\
\hline Gulbin & 7.38 & 254.7 & 9.1 & 3.5 & 32.4 & 14.3 & 9.6 & 1.49 \\
\hline Hańcza & 303.56 & 118648.0 & 105.6 & 39.1 & 2.9 & 4.0 & 6.5 & 0.62 \\
\hline Jaczno & 40.64 & 3980.6 & 25.7 & 9.8 & 4.0 & 5.9 & 3.2 & 1.84 \\
\hline Jegłóweczek & 1.81 & 56.9 & 8.3 & 3.1 & 7.3 & 8.9 & 17.8 & 0.50 \\
\hline Jegłówek & 19.81 & 1835.2 & 27.7 & 9.9 & 7.4 & 5.2 & 6.2 & 0.84 \\
\hline Kameduł & 25.26 & 1767.4 & 26.2 & 7.0 & 5.6 & 8.9 & 4.2 & 2.12 \\
\hline Kluczysko & 3.67 & 199.7 & 13.8 & 5.4 & 19.7 & 19.0 & 14.4 & 1.32 \\
\hline Kojle & 17.26 & 1679.4 & 32.3 & 9.7 & 4.0 & 6.5 & 4.3 & 1.51 \\
\hline Kopane & 16.15 & 918.4 & 18.8 & 5.7 & 14.2 & 14.1 & 7.6 & 1.86 \\
\hline Krejwelek & 8.76 & 249.3 & 5.5 & 2.8 & 21.9 & 15.7 & 9.0 & 1.74 \\
\hline Linówek & 2.85 & 67.6 & 5.9 & 2.4 & 10.2 & 7.6 & 15.8 & 0.48 \\
\hline Okrągłe & 15.03 & 645.9 & 7.4 & 4.3 & 20.5 & 17.5 & 9.4 & 1.86 \\
\hline Perty & 19.51 & 1446.2 & 32.6 & 7.4 & 5.1 & 5.9 & 6.3 & 0.94 \\
\hline Pogorzałek & 5.79 & 340.8 & 17.6 & 5.9 & 14.2 & 15.6 & 11.2 & 1.39 \\
\hline Postawelek & 3.35 & 67.9 & 4.0 & 2.0 & 24.6 & 11.3 & 8.5 & 1.33 \\
\hline Przechodnie & 23.89 & 747.2 & 5.4 & 3.1 & 27.4 & 18.3 & 7.7 & 2.38 \\
\hline Purwin & 1.41 & 38.9 & 4.3 & 2.8 & 14.3 & 10.0 & 10.8 & 0.93 \\
\hline Purwinek & 0.44 & 6.8 & 3.3 & 1.5 & 35.4 & 16.0 & 4.6 & 3.48 \\
\hline Szurpiły & 84.35 & 9450.8 & 47.1 & 11.2 & 4.4 & 9.4 & 2.6 & 3.62 \\
\hline Udziejek & 7.01 & 230.7 & 6.9 & 3.3 & 32.3 & 17.8 & 6.6 & 2.70 \\
\hline Wodziłki & 3.73 & 115.7 & 5.4 & 3.1 & 27.0 & 9.8 & 10.6 & 0.92 \\
\hline
\end{tabular}


subsurface incident light remains (e.g. Kirk 1996; Kalff 2003), according to the formula:

$$
z_{e u}=\ln (100) / \bar{K}_{d, P A R} \approx 4.6 / \bar{K}_{d, P A R}[\mathrm{~m}] .
$$

The mean light transmittance into the water column, expressing the relative amount of solar radiation penetrating a one-metre layer of water, was determined as:

$$
\bar{T}_{P A R}=100 \cdot \exp \left(-\bar{K}_{d, P A R}\right)[\%] .
$$

Knowledge of the mean diffuse attenuation coefficient of downward irradiance in the PAR range allowed the determination of mean epilimnion irradiance $\left(\bar{E}_{m i x}\right)$, expressed as a percentage of the surface incident light (Sterner et al. 1997):

$$
\bar{E}_{\text {mix }}=100 \cdot\left[\left(1-\exp \left(-\bar{K}_{d, P A R} \cdot z_{\text {mix }}\right)\right) /\left(\bar{K}_{d, P A R} \cdot z_{\text {mix }}\right)\right][\%] .
$$
layer).

where: $z_{\text {mix }}$ is the depth of the epilimnion (mixing

Supplementary to the radiometric measurements were the measurements of water transparency performed with the Secchi disc. Moreover, true water colour was specified. Water colour was determined by spectrophotometry $(\lambda=340 \mathrm{~nm})$ on permeates of water samples (Whatman GF/C filter) collected from surface layer ( $1 \mathrm{~m}$ depth).

To evaluate the long-term trends of selected optical characteristics of SLP lake water, the unpublished results of the authors' hydro-optical measurements performed in the years 1997-2016 were used, together with the materials available in the literature (Koźmiński 1932; Stangenberg 1936, 1937; Szczepański 1961; Górniak et al. 2007; Zdanowski 2008; Jekatierynczuk-Rudczyk et al. 2014; Górniak et al. 2016).

\section{Results}

\section{Optically significant constituents of water (OSC)}

The concentration of chlorophyll- $a$ in surface water ranged from $2.9 \mu \mathrm{g} \mathrm{dm}^{-3}$ in Lake Hańcza to 35.4 $\mu \mathrm{g} \mathrm{dm}^{-3}$ in Lake Purwinek. The mean concentration of chlorophyll- $a$ was $16.2 \mu \mathrm{g} \mathrm{dm}^{-3}$, and the median value was $14.2 \mu \mathrm{g} \mathrm{dm}^{-3}$. Concentrations below $8 \mu \mathrm{g} \mathrm{\textrm {dm } ^ { - 3 }}$ (maximum for oligotrophy) were found in eight lakes, and values exceeding $25 \mu \mathrm{g} \mathrm{dm}^{-3}$ (eutrophy) in six lakes - mainly medium deep and shallow polymictic water bodies (Table 1). In medium deep and shallow lakes the median of chlorophyll- $a$ concentrations was $24.5 \mu \mathrm{g}$ $\mathrm{dm}^{-3}$.

Concentration of dissolved organic matter (humic substances) was expressed in colour units of the platinum-cobalt scale. The true water colour in the studied lakes ranged from 2.6 to $18.1 \mathrm{mg} \mathrm{Pt} \mathrm{dm}{ }^{-3}$. The lowest concentration of humic substances was reported in Lake Szurpiły, the highest in Lake Błędne. Oligohumic water $\left(T C>10 \mathrm{mg} \mathrm{Pt} \mathrm{dm}^{-3}\right)$ was found in only eight lakes. In very deep lakes $\left(z_{\max }>20 \mathrm{~m}\right)$ true water colour did not exceed $6.5 \mathrm{mg} \mathrm{Pt} \mathrm{dm}^{-3}$ (Table 1). The mean value for all 23 lakes was 9.1, and the median $8.5 \mathrm{mg} \mathrm{Pt}$ $\mathrm{dm}^{-3}$

Turbidity, expressed in nephelometric turbidity units, ranged from 4.0 to $19.0 \mathrm{NTU}$ (Table 1). In very deep lakes water turbidity (mean $=6.5$ NTU; median $=5.9 \mathrm{NTU}$ ) was twice lower than in other lakes (mean $=13.2 \mathrm{NTU}$; median 14.3 NTU). Among the deepest lakes, the highest turbidity was found in Lake Szurpiły (9.4 NTU). In 12 lakes of the SLP turbidity did not exceed 10 NTU. The highest turbidity was recorded in deep lakes (mean $=16.0 \mathrm{NTU}$ ).

The determined turbidity values (TUR), and true water colour $(T C)$ are empirical indicators relating to the properties of the aqueous medium in terms of, respectively, the scattering and absorption of light penetrating the water column. The ratio of TUR/TC thus defines the relative relationships between the light scattering and absorption in water. The higher the value the greater the share of the scattering component in the total attenuation of the light beam. The calculated relations TUR/TC ranged from 0.34 (Lake Błędne) to 3.62 (Lake Szurpiły). The mean value in the whole group of lakes was 1.5 and the median 1.4. There were no differences of the TUR/TC in different size groups of the lakes.

\section{Optical characteristics of the water}

Secchi disc transparency $\left(z_{S D}\right)$ ranged from 1.1 to $6.0 \mathrm{~m}$. In both large and deep lakes transparency was significantly higher than in other water bodies. The mean $z_{S D}$ values were, respectively, 4.1 and $2.0 \mathrm{~m}$, and the median was 3.8 and $1.7 \mathrm{~m}$. The transparency median determined for all lakes was 2.2 , while the mean was $2.7 \mathrm{~m}$. The greatest transparency of the water was recorded in Lakes Hańcza, Jegłówek and Jaczno, in which $z_{S D} \geq 5.0 \mathrm{~m}$ (Table 2).

In contrast to the Secchi disc transparency, the mean and median values of the diffuse attenuation coefficient of photosynthetically active radiation $\left(K_{d, P A R}\right)$ were the lowest in deep lakes and were, respectively, 0.550 and $0.531 \mathrm{~m}^{-1}$. In shallower lakes, the $K_{d, P A R}$ coefficients were almost three times higher (mean $=1.402$ $\mathrm{m}^{-1}$; median $1.456 \mathrm{~m}^{-1}$ ). Extreme $K_{d, P A R}$ values were reported in Lakes Kluczysko $\left(2.003 \mathrm{~m}^{-1}\right)$ and Jaczno $\left(0.436 \mathrm{~m}^{-1}\right)$. The spectrum of the diffuse attenuation coefficient for downward irradiance indicates that in the SLP lakes the least attenuated is green-yellow light 
Table 2. Characteristics of underwater light field (PAR: $400-700 \mathrm{~nm}$ ) in lakes within the Suwałki Landscape Park. Explanation: $\bar{K}_{d, P A R}-$ mean diffuse attenuation coefficient for downward irradiance, $\bar{T}_{P A R}$ - mean light transmittance, $z_{S D}$ - Secchi disc transparency, $z_{e u}-$ euphotic zone depth (depth of $1 \%$ light), $z_{\text {mix }}$ - theoretical mixing depth (epilimnion depth) according to Patalas (1960), $z_{\max }-$ maximum depth, $E_{S D}-$ irradiance at a Secchi disc depth, $E_{0}$ - incident irradiance, $\bar{E}_{\text {mix }}$ - mean irradiance in the mixed layer as a fraction of incident light (in cases where the theoretical depth of mixing is greater than the maximum depth of the lake /marked by asterisk/ - mean irradiance in the lake), $\bar{E}_{S D}-$ mean irradiance in the Secchi disc visibility layer as a fraction of incident light, $V_{e u}$ - euphotic zone volume as a percentage of total lake volume

\begin{tabular}{|c|c|c|c|c|c|c|c|c|c|c|c|c|}
\hline Lake & $\begin{array}{l}\bar{K}_{d, P A R} \\
{\left[\mathrm{~m}^{-1}\right]}\end{array}$ & $\begin{array}{l}\bar{T}_{P A R} \\
{[\%]}\end{array}$ & $\begin{array}{l}z_{S D} \\
{[\mathrm{~m}]}\end{array}$ & $\begin{array}{c}\bar{K}_{d} z_{S D} \\
{[-]}\end{array}$ & $\begin{array}{c}Z_{\text {eu }} \\
{[\mathrm{m}]}\end{array}$ & $\begin{array}{l}Z_{\text {mix }} \\
{[\mathrm{m}]}\end{array}$ & $\begin{array}{c}Z_{e} / Z_{\max } \\
{[\%]}\end{array}$ & $\begin{array}{c}z_{\text {e }} / z_{\text {mix }} \\
{[\%]}\end{array}$ & $\begin{array}{c}E_{S D} / E_{0} \\
{[\%]}\end{array}$ & $\begin{array}{l}\bar{E}_{\text {mix }} \\
{[\%]}\end{array}$ & $\begin{array}{l}\bar{E}_{S D} \\
{[\%]}\end{array}$ & $\begin{array}{l}V_{\text {eu }} \\
{[\%]}\end{array}$ \\
\hline Błędne & 1.169 & 31.1 & 2.2 & 2.6 & 3.9 & 1.9 & 81 & 205 & 7.6 & 40 & 36 & 98 \\
\hline Bocznel & 0.967 & 38.0 & 3.0 & 2.9 & 4.8 & 4.1 & 123 & 117 & 5.5 & $26^{*}$ & 33 & 100 \\
\hline Gulbin & 1.456 & 23.3 & 1.5 & 2.2 & 3.2 & 2.6 & 35 & 123 & 11.3 & 26 & 41 & 68 \\
\hline Hańcza & 0.451 & 63.7 & 6.0 & 2.7 & 10.2 & 7.4 & 10 & 138 & 6.7 & 29 & 34 & 23 \\
\hline Jaczno & 0.436 & 64.7 & 5.0 & 2.2 & 10.6 & 4.6 & 41 & 230 & 11.3 & 43 & 41 & 78 \\
\hline Jegłóweczek & 1.266 & 28.2 & 3.8 & 4.8 & 3.6 & 2.0 & 43 & 180 & 0.8 & 36 & 21 & 75 \\
\hline Jegłówek & 0.529 & 58.9 & 5.1 & 2.7 & 8.7 & 3.6 & 31 & 242 & 6.7 & 45 & 35 & 64 \\
\hline Kameduł & 0.667 & 51.3 & 3.0 & 2.0 & 6.9 & 3.6 & 26 & 192 & 13.5 & 38 & 43 & 70 \\
\hline Kluczysko & 2.003 & 13.5 & 1.7 & 3.4 & 2.3 & 2.1 & 17 & 110 & 3.3 & 23 & 28 & 37 \\
\hline Kojle & 0.531 & 58.8 & 3.6 & 1.9 & 8.7 & 3.2 & 27 & 272 & 14.8 & 48 & 45 & 67 \\
\hline Kopane & 1.326 & 26.6 & 1.9 & 2.5 & 3.5 & 3.3 & 19 & 106 & 8.1 & 23 & 36 & 50 \\
\hline Krejwelek & 1.579 & 20.6 & 1.7 & 2.7 & 2.9 & 2.8 & 53 & 104 & 6.8 & 22 & 35 & 81 \\
\hline Linówek & 1.041 & 35.3 & 3.2 & 3.3 & 4.4 & 1.8 & 75 & 244 & 3.6 & 45 & 29 & 97 \\
\hline Okrągłe & 1.635 & 19.5 & 1.3 & 2.1 & 2.8 & 3.1 & 38 & 90 & 11.9 & 20 & 41 & 58 \\
\hline Perty & 0.586 & 55.7 & 3.8 & 2.2 & 7.9 & 3.5 & 24 & 226 & 10.8 & 42 & 40 & 73 \\
\hline Pogorzałek & 1.635 & 19.5 & 1.6 & 2.6 & 2.8 & 3.4 & 16 & 82 & 7.3 & 18 & 35 & 41 \\
\hline Postawelek & 1.262 & 28.3 & 1.9 & 2.4 & 3.7 & 2.1 & 93 & 176 & 9.1 & 35 & 38 & 99 \\
\hline Przechodnie & 1.539 & 21.5 & 1.1 & 1.7 & 3.0 & 3.6 & 56 & 83 & 18.4 & 18 & 48 & 79 \\
\hline Purwin & 1.110 & 33.0 & 2.2 & 2.4 & 4.2 & 1.6 & 98 & 263 & 8.7 & 47 & 37 & 100 \\
\hline Purwinek & 1.468 & 23.0 & 1.7 & 2.5 & 3.1 & 1.2 & 94 & 258 & 8.2 & 47 & 37 & 100 \\
\hline Szurpiły & 0.647 & 52.4 & 2.3 & 1.5 & 7.1 & 5.2 & 15 & 137 & 22.6 & 29 & 52 & 50 \\
\hline Udziejek & 1.568 & 20.8 & 1.3 & 2.0 & 2.9 & 2.2 & 42 & 132 & 13.0 & 28 & 43 & 68 \\
\hline Wodziłki & 1.387 & 25.0 & 2.3 & 3.2 & 3.3 & 1.8 & 61 & 183 & 4.1 & 37 & 30 & 82 \\
\hline Minimum: & 0.436 & 13.5 & 1.1 & 1.5 & 2.3 & 1.2 & 10 & 82 & 0,8 & 18 & 21 & 23 \\
\hline Maximum: & 2.003 & 64.7 & 6.0 & 4.8 & 10.6 & 7.4 & 123 & 272 & 22.6 & 48 & 52 & 100 \\
\hline Average: & 1.140 & 35.3 & 2.7 & 2.5 & 5.0 & 3.1 & 49 & 169 & 9.3 & 33 & 37 & 72 \\
\hline Median: & 1.262 & 28.3 & 2.2 & 2.5 & 3.6 & 3.1 & 41 & 176 & 8.2 & 35 & 37 & 73 \\
\hline
\end{tabular}

$(\lambda=565 \mathrm{~nm})$, followed by blue-green $(\lambda=490 \mathrm{~nm})$ or red light $(\lambda=670 \mathrm{~nm})$, depending on the quantitative composition of the OSC in different lakes (Fig. 2). In the lakes with the best light conditions, red light was most absorbed with a wavelength $\lambda=780 \mathrm{~nm}$, which penetrates only a 1.5 metre layer of water. In lakes with a higher content of humic substances the underwater light field was slightly changed, and the most absorbed light was of a violet colour $(\lambda=380 \mathrm{~nm})$, which illuminates the water column to a depth of $1.0 \mathrm{~m}$.

The value of the product $\bar{K}_{d} \cdot z_{S D}$ ranged from 1.5 in Lake Szurpiły to 4.8 in Lake Jegłóweczek. Mean and median designated for the entire population of the lakes were equal and amounted to 2.5 (Table 2). The lowest values of $\bar{K}_{d} \cdot z_{S D}$ were observed in very deep lakes $(2.2$ \pm 0.4 ), the highest in the deep and medium deep lakes $(2.8 \pm 0.8)$.

The consequence of the large variation of the attenuation coefficient for downward irradiation in the SLP lakes were significant differences in PAR transmit-

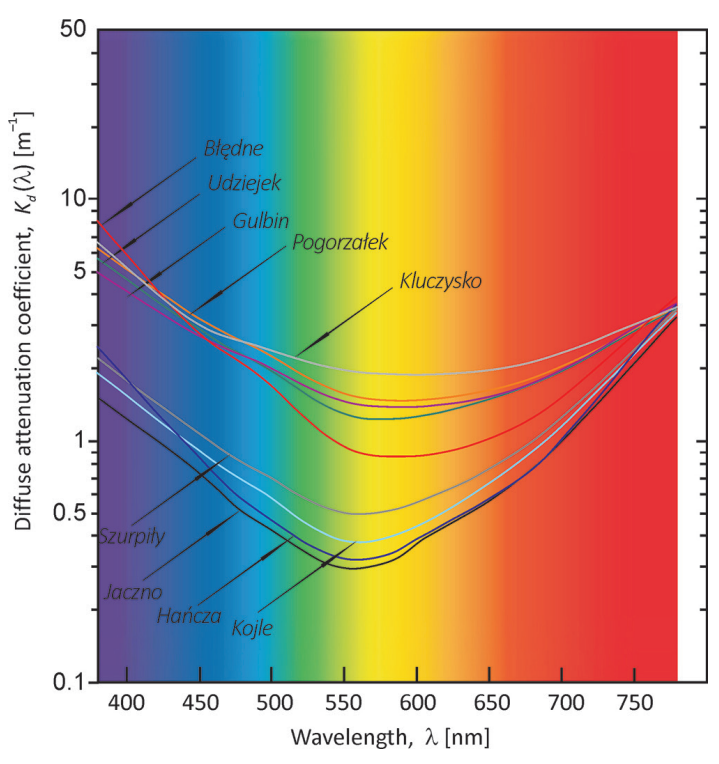

Fig. 2. Spectral variation of diffuse attenuation coefficient for downward irradiance $\left(\mathrm{K}_{\mathrm{d}}(\lambda)\right.$ in selected lakes of the Suwałki Landscape Park 
tance $\left(T_{P A R}\right)$ and euphotic depth $\left(z_{e u}\right)$. In the cleanest lakes (Jaczno, Hańcza) transmittance exceeded $60 \%$, and euphotic depths were greater than $10 \mathrm{~m}$. The euphotic zone depths were substantially larger than the theoretical depth of wind mixing. Only in three lakes (Okrągłe, Pogorzałek, Przechodnie) was the opposite observed. In Lake Bocznel the calculated range of the euphotic zone was found to be greater than the maximum depth of the lake (Table 2).

The percentage of euphotic zone volume $\left(V_{e u}\right)$ in the total volume of lake water ranged from 23 to $100 \%$. A euphotic zone volume of less than 50\% was recorded for Lakes Hańcza, Kluczysko, Pogorzałek, Kopane and Szurpiły. In the case of Lakes Hańcza and Szurpiły, the small volume of the euphotic zone was conditioned by the morphometric factor. In both water bodies, the ratio of the euphotic zone to a maximum depth did not exceed $15 \%$. For the remaining three lakes, the determinants were the optical properties of water, and - to a lesser extent - the depth conditions (Table 2).

The percentage of incident light $\left(E_{0}\right)$ at Secchi depth $\left(E_{S D}\right)$ ranged from 0.8 (Jegłóweczek) to $26.6 \%$ (Szurpiły). In general, the relative amount of light at the Secchi depth was formed mainly by the ratio of the concentration of suspended solids (TUR) to dissolved coloured organic matter (TC). In $49 \%$ the ratio TUR/TC explains the variability of the $E_{S D} / E_{0}$ in the SLP lakes. The relationship between variables is positive.

The average irradiance of the water layer to the Secchi depth ranged from 21 to $52 \%$, and the median was $37 \%$. Since the theoretical depths of wind mixing proved to be only slightly greater than the Secchi disc depth, the irradiation of the theoretical mixing layer was similar and ranged from 18 (Pogorzałek, Przechodnie) to $48 \%$ (Kojle) (Table 2).

\section{Discussion}

The Lithuanian Lakeland, which includes the mesoregion of the East-Suwałki Lakeland, contains lakes that show the greatest transparency from among the other geographical macroregions of northern Poland (Borowiak 2014). The interquartile of water transparency of the lakes of the Lithuanian Lakeland with an area of more than $50 \mathrm{hm}^{2}$ is defined by an upper and lower quartile of 1.95 and $3.75 \mathrm{~m}$. The lakes of the Suwałki Landscape Park (SLP), although much smaller (out of 23 lakes only two are larger than $50 \mathrm{hm}^{2}$ ), have similar characteristics of water transparency. In 2013 the middle fifty range which included $50 \%$ of the observations displayed transparency values of 1.70 and 3.60 m. Mid-summer (July-August) Secchi disc transparency values of the SLP lakes for the period 1997-2015, ex- pressed as a median value, ranged from 1.2 (Krejwelek, Przechodnie, Udziejek) to $5.1 \mathrm{~m}$ (Hańcza).

Multi-year observations of changes in water transparency of dimictic Lakes Hańcza and Szurpiły showed that in mid-summer water transparency of these lakes is closely linked to the air temperature in the spring. Higher water transparency in summer was observed in the years when spring air temperature was higher (Fig. 3A). Cold springs favoured the occurrence of worse conditions for the transmission of light in the summer. Spring and summer chlorophyll- $a$ concentrations are negatively correlated with each other (Fig. $3 \mathrm{~B})$. Under the conditions of warm spring, the growth of phytoplankton took place earlier, and the spring (May-June) mean concentrations of chlorophyll- $a$ were therefore much higher than mean concentrations observed in the mid-summer (July-August). In the years in which spring phytoplankton blooms were more intense, the pool of available phosphorus in surface waters underwent significant reduction (Fig. 3C), which was a factor limiting the amount of primary production in the summer.

For lake ecosystems in which light regulates the majority of internal processes, the depth of the euphotic zone $\left(z_{e u}\right)$ is an important ecological boundary. The range of this zone in the SLP lakes was from 2.3 to 10.6 $\mathrm{m}$, and the median value was $3.6 \mathrm{~m}$ (Table 2). Clearly the depth of the euphotic zone is defined by the diffuse attenuation coefficient for downward irradiance in the $P A R$ range. Showing a strong statistical relationship with, Secchi disc transparency is sometimes commonly used to estimate the euphotic depth. Because a greater impact on water transparency (Secchi depth) is exerted by suspended matter in water rather than the coloured organic matter dissolved in it, there is no fixed conversion factor (proportionality constant) of Secchi depth to euphotic depth. These relations are further complicated by the heterogeneous distribution of the suspension in the water column. Consequently, the relative value for downward irradiance at the Secchi depth $\left(E_{S D} / E_{0}\right)$ is sometimes variable, and the proportionality constant varies significantly (Reynolds, 1984; Koenings and Edmundson, 1991; Silsbe et al. 2006). As a result, lakes with a similar euphotic depth can show variable transparency (Fig. 4A). In the SLP lakes the proportionality constant ranged from 0.95 (Jegłóweczek) to 3.09 (Szurpiły). On average it was 1.84 , which is typical for clean water or water coloured with dissolved organic matter (Borowiak 2011). The value of $z_{e u} / z_{S D}$ for most lakes of northern Poland ranges from 2.4 to 2.5 (FaraśOstrowska and Lange 1998; Borowiak 2011). Similarly to the SLP lakes, relationships combining euphotic depth with water transparency have been found in the 

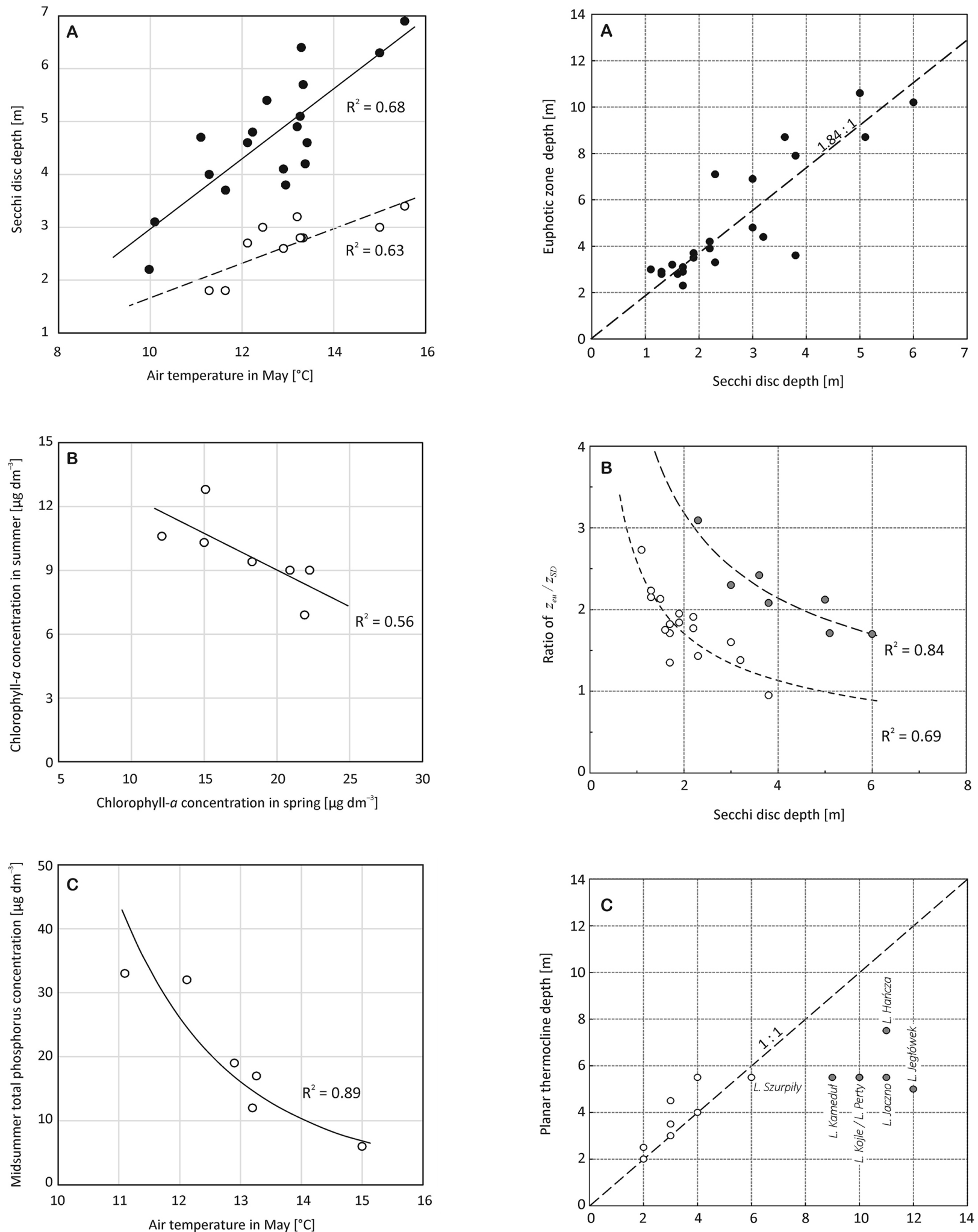

Fig. 3. Relationships between: A - air temperature in May and Sechi disc depth in lakes Hańcza (black circles) and Szurpiły (white circles); B - mean chlorophyll- $a$ concentration in spring (May-June) and mid-summer (July-August); $\mathrm{C}$ - air temperature in May and total phosphorous concentration during mid-summer in Lake Szurpiły

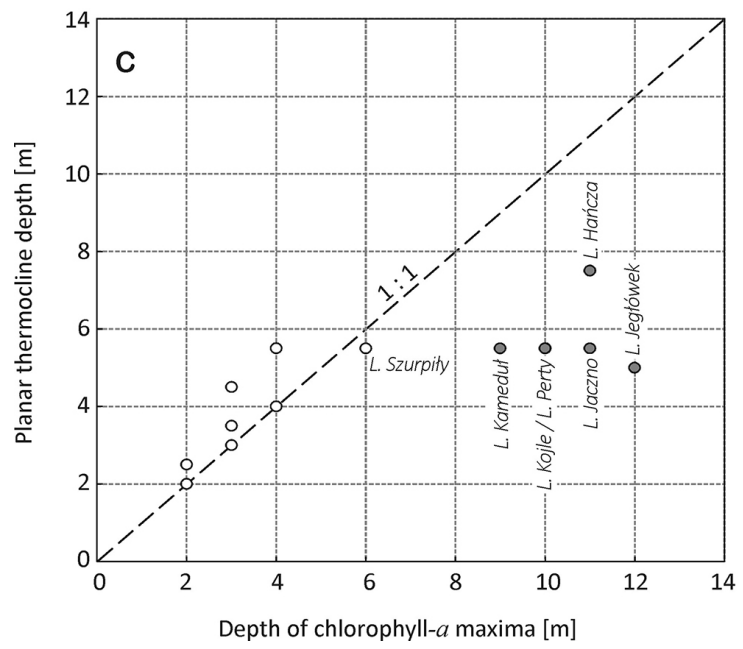

Fig. 4. Relationships between: A - Secchi disc depth and euphotic zone depth; B - Secchi disc depth and the ratio of $z_{e u} / z_{S D} ; \mathrm{C}$ - depth of the absolute chlorophyll- $a$ concentration and depth of the maximum density gradient observed in lakes of the Suwałki Landscape Park 
lakes of the National Park "Bory Tucholskie" (Ficek and Borowiak 2016).

Comparison of the ratios of $z_{e u} / z_{S D}$ showed that the SLP lakes are clearly divided into two different optical groups (Fig. 4B). The first one includes large and very deep dimictic lakes (Hańcza, Jaczno, Jegłówek, Kameduł, Kojle, Perty, Szurpiły). The second includes the remaining lakes of the park, mainly medium deep and shallow. In these lakes, the measured concentration of optically significant constituents of water, dissolved and suspended, was over twofold larger (Table 1). Thus, with similar water transparencies their sunlight zones were much shallower than in the case of the lakes in the first group. Extensive euphotic zones in large and very deep lakes were the cause of deep chlorophyll maxima (DCM) occurance in them (Abbot et al. 1984; Reynolds 1992; Camacho 2006). The absolute maxima of chlorophyll- $a$ concentrations in these lakes were observed in the upper hypolimnion at depths of 9-12 m (between the 1 and $0.1 \%$ light level), well below the layer of the water maximum density gradient (Fig. 4C). Photon flux density at the DCM depth ranged from 2.7 (Jegłówek) to $12.7 \mu \mathrm{E} \mathrm{cm}^{-2} \mathrm{~s}^{-1}$ (Jaczno).

The spectra of the $\bar{K}_{d}(\lambda)$ coefficient (Fig. 2), designated for the euphotic layer of the studied lakes, confirm the optical duality of the SLP lakes. Using spectral diffuse attenuation coefficients for downward irradiance and their integral values in the range of photosynthetically active radiation $(P A R)$, a division of lakes into optical types was conducted according to criteria presented by Borowiak $(2009,2011)$. The SLP lakes were classified into two optical types of water (Table 3 ).

The largest group (16 lakes) includes the lakes of the optical type IIIb. This is one of the most common optical lake types in northern Poland (Borowiak 2011; Borowiak et al. 2016; Ficek and Borowiak 2016). These are the water bodies in which the optical conditions of the water are formed by suspended particles, mostly phytoplankton. Summer concentrations of chlorophyll- $a$ in the surface layer of the lakes were $28.8 \pm 8.5$ $\mu \mathrm{g} \mathrm{dm}{ }^{-3}$, and the turbidity was $13.3 \pm 4.3 \mathrm{NTU}$. Another factor affecting the optical properties of these lakes was higher concentration of humic substances $(T C=11.03$ $\pm 3.9 \mathrm{mg} \mathrm{Pt} \mathrm{dm}{ }^{-3}$ ). Taking as a grouping criterion only the attenuation coefficient for downward irradiance in the $P A R$ region $\left(\bar{K}_{d, P A R}\right)$, six lakes in this group can be classified as type IIIC (Table 4).

The seven deepest lakes of the SLP represent the optical type II, also common in Poland. These lakes have the lowest concentrations of optically significant constituents of water. Summer chlorophyll- $a$ concentrations in the surface layer were $4.8 \pm 1.3 \mu \mathrm{g} \mathrm{dm}^{-3}$, turbidity was $6.5 \pm 1.8 \mathrm{NTU}$, and the true colour of the water was $4.8 \pm 1.5 \mathrm{mg} \mathrm{Pt} \mathrm{dm}^{-3}$. Very little colouring of water (ultraoligohumic lakes) makes the optical properties of these lake waters primarily determined by phytoplankton, as evidenced from the product $\bar{K}_{d} z_{S D}$ in the range of 1.9-2.7 (Koenings and Edmundson 1991; Reinart et al. 2003; Borowiak 2011). In the case of Lake Szurpily, for which this parameter is 1.5 , a greater impact on the distribution of underwater light field is exerted by nonphytoplankton particles.

Relationships linking the attenuation coefficient for downward irradiance within the $P A R$ range with optically significant constituents of the water in the studied Suwałki lakes are similar to those found in harmonious lakes of the "Tuchola Forest” National Park (Table 4). The main process attenuating light transmission in the SLP lake water was its scattering on suspended solid particles. In the lakes located in the "Tuchola Forest" National Park, the participation of scattering in the total attenuation of irradiance exceeds 60\% (Ficek and Borowiak 2016). As the impact of true water colour on irradiance attenuation in SLP lake waters was much

Table 3. Division of the Suwałki Landscape Park lakes into optical types. In parentheses are given lakes for which sequence of spectral attenuation coefficients is the same as in lakes of type IIIb, but $\bar{K}_{d, P A R}$ values are in the range of $1.51-2.20 \mathrm{~m}^{-1}$

\begin{tabular}{|c|c|c|}
\hline Type & Optical characteristics & Lake \\
\hline I & $\begin{array}{c}K_{d}(565)<K_{d}(490)<K_{d}(443)<K_{d}(670) \\
\bar{K}_{d} \text { PAR } \\
=0.15-0.35 \mathrm{~m}^{-1}\end{array}$ & - \\
\hline II & $\begin{array}{c}K_{d}(565)<K_{d}(490)<K_{d}(670)<K_{d}(443) \\
\bar{K}_{d, \text { PAR }}=0.36-0.70 \mathrm{~m}^{-1}\end{array}$ & Hańcza, Jaczno, Jegłówek, Kameduł, Kojle, Perty, Szurpiły \\
\hline IIla & $\begin{array}{c}K_{d}(565)<K_{d}(670)<K_{d}(490)<K_{d}(443) \\
\bar{K}_{d, \text { PAR }}=0.71-0.90 \mathrm{~m}^{-1}\end{array}$ & - \\
\hline IIIb & $\begin{array}{c}K_{d}(565)<K_{d}(670)<K_{d}(490)<K_{d}(443) \\
\bar{K}_{d, \text { PAR }}=0.91-1.50 \mathrm{~m}^{-1}\end{array}$ & $\begin{array}{l}\text { Błędne, Bocznel, Gulbin, Jegłóweczek, Kluczysko, Kopane, Krejwelek, Linówek, Okrągłe, } \\
\text { Pogorzałek, Postawelek, Przechodnie, Purwin, Purwinek, Udziejek, Wodziłki }\end{array}$ \\
\hline IIIc & $\begin{array}{c}K_{d}(565)<K_{d}(670)<K_{d}(490)<K_{d}(780) \\
\bar{K}_{d \text { PAR }}=1.51-2.20 \mathrm{~m}^{-1}\end{array}$ & (Kopane), (Krejwelek), (Okrągłe), (Pogorzałek), (Przechodnie), (Udziejek) \\
\hline IIId & $\begin{array}{c}K_{d}(565)<K_{d}(670)<K_{d}(780)<K_{d}(490) \\
\bar{K}_{d, P A R}=2.21-2.50 \mathrm{~m}^{-1}\end{array}$ & - \\
\hline IVa & $\begin{array}{c}K_{d}(670)<K_{d}(565)<K_{d}(780)<K_{d}(490) \\
\bar{K}_{d, P A R}=2.51-3.90 \mathrm{~m}^{-1}\end{array}$ & - \\
\hline
\end{tabular}


Table 4. Empirical relationships between diffuse attenuation coefficient for downward irradiance $\left(\bar{K}_{d, P A R}\right)$ and concentration of optically significant constituents of water in the Suwałki Landscape Park (SLP) lakes and other lake groups in Poland

\begin{tabular}{|c|c|c|c|c|c|}
\hline Parameter & Formula & $r^{2}$ & $N$ & Lake group & References \\
\hline Chlorophyll-a, Chl $\left[\mathrm{\mu g} \mathrm{dm}^{-3}\right]$ & $\bar{K}_{d, P A R}=0.277 \cdot(C h /)^{0.523}$ & 0.77 & 23 & SLP & \multirow{3}{*}{ this study } \\
\hline Turbidity, TUR [NTU] & $\bar{K}_{d, P A R}=0.140 \cdot(T U R)^{0.869}$ & 0.74 & 23 & SLP & \\
\hline True color, TC [mg Pt dm $\left.{ }^{-3}\right]$ & $\bar{K}_{d, P A R}=0.349 \cdot(T C)^{0.523}$ & 0.35 & 23 & SLP & \\
\hline True color, TC [mg Pt dm-3] & $\bar{K}_{d, P A R}=0.438 \cdot(T C)^{0.435}$ & 0.73 & 33 & Lobelia lakes & \multirow{3}{*}{ Borowiak et al. (2016) } \\
\hline Turbidity, TUR [NTU] & $\bar{K}_{d, P A R}=0.075 \cdot(T U R)^{1.232}$ & 0.56 & 33 & Lobelia lakes & \\
\hline Chlorophyll-a, Chl $\left[\mathrm{\mu g} \mathrm{dm}^{-3}\right]$ & $\bar{K}_{d, P A R}=0.246 \cdot(C h l)^{0.568}$ & 0.51 & 33 & Lobelia lakes & \\
\hline Turbidity, TUR [FNU] & $\bar{K}_{d, P A R}=0.351 \cdot(T U R)^{0.705}$ & 0.91 & 18 & Tuchola Forest NP & \multirow{3}{*}{ Ficek and Borowiak (2016) } \\
\hline Chlorophyll-a, Chl $\left[\mathrm{\mu g} \mathrm{dm}^{-3}\right]$ & $\overline{\bar{K}}_{d, P A R}=0.346 \cdot(C h /)^{0.409}$ & 0.80 & 18 & Tuchola Forest NP & \\
\hline True color, TC [mg Pt dm $\left.{ }^{-3}\right]$ & $\bar{K}_{d, P A R}=0.358 \cdot(T C)^{0.612}$ & 0.65 & 18 & Tuchola Forest NP & \\
\hline True color, TC [mg Pt dm $\left.{ }^{-3}\right]$ & $\bar{K}_{d, P A R}=0.248 \cdot(T C)^{0.584}$ & 0.65 & 105 & Pomeranian lakes & \multirow{3}{*}{ Borowiak (2011) } \\
\hline Turbidity, TUR [NTU] & $\bar{K}_{d, P A R}=0.493 \cdot(T U R)^{0.536}$ & 0.61 & 105 & Pomeranian lakes & \\
\hline Chlorophyll-a, Chl $\left[\mathrm{\mu g} \mathrm{dm}^{-3}\right]$ & $\bar{K}_{d, P A R}=0.172 \cdot(\mathrm{Ch} /)^{0.507}$ & 0.57 & 105 & Pomeranian lakes & \\
\hline
\end{tabular}

smaller, it could be assumed that the percentage of light absorption was also lower in these lakes.

As the attenuation coefficient for downward irradiance is statistically strongly correlated with parameters widely used for assessing trophic status of lakes (concentration of chlorophyll- $a$, transparency), it is also an effective quantifier of trophic status (Talling 1971; Howard-Wiliams and Vincent 1984; Davies-Colley et al. 2003; Borowiak 2011). Using a hydro-optical criterion developed for Polish lakes for assessing their trophic status (Borowiak 2011; Borowiak et al. 2016), it should be noted that the SLP lakes are very diverse in terms of their trophy. Lakes Kluczysko and Pogorzałek should be regarded as hypertrophic, while four others (Krejwelek, Okrągłe, Przechodnie and Udziejek) show the initial stage of hypertrophy. The largest group (10 lakes) are eutrophic lakes, which include Lakes Błędne, Bocznel, Gulbin, Jegłóweczek, Kopane, Linówek, Postawelek, Purwin, Purwinek and Wodziłki. All of the lakes assigned to the optical type IIIb are eutrophic or hypertrophic. The remaining SLP lakes are mesotrophic. Features of $\alpha$-mesotrophy are manifested by Lakes Hańcza and Jaczno, while Lakes Jegłówek, Kameduł, Kojle, Perty and Szurpiły are $\beta$-mesotrophic.

Compared to the study of 2003 (Zieliński et al. 2006; Górniak et al. 2007), the trophic state of six lakes had deteriorated. These are the lakes which show symptoms of hypertrophy. With regard to four other lakes (Jegłówek, Kameduł, Kojle, Szurpiły), their previous trophic status was not confirmed. In 2003 they were recognised as eutrophic, while in the light of 2013 optical tests they are $\beta$-mesotrophic lakes. JekatierynczukRudczyk et al. (2014), using Carlson's trophic state indices, classified Lake Jegłówek as mesotrophic, but lakes Kameduł, Kojle and Szurpiły as eutrophic. According to other trophic indices the last three lakes were rather mesotrophic than eutrophic (Jekatierynczuk-Rudczyk et al. 2014).

The oligotrophic status of Lake Hańcza, widely mentioned in the literature (Koźmiński 1932; Czeczuga and Grądzki 1970; Czeczuga 1994) was not con-
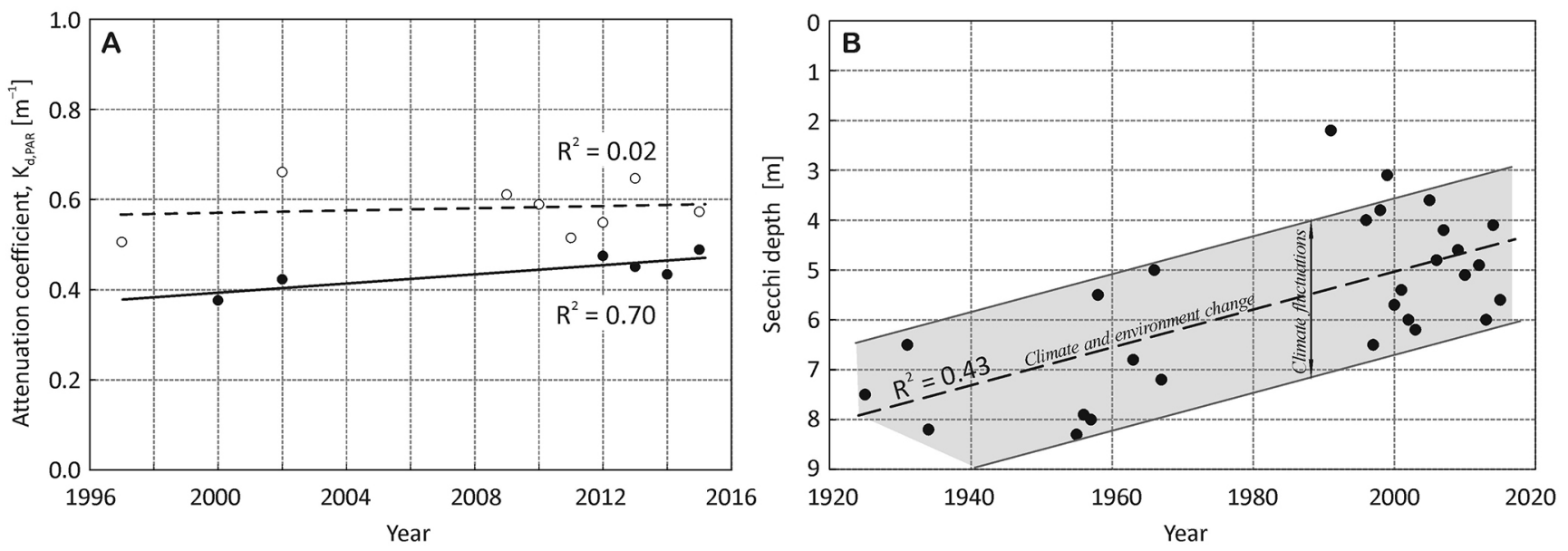

Fig. 5. Multi-annual changes in the diffuse attenuation coefficient for downward irradiance in Lake Hańcza (black circles) and Lake Szurpiły (white circles) - A, and multi-annual changes in Secchi disc depth during mid-summer in Lake Hańcza - B 
firmed. In the light of periodic measurements of the optical properties of the lake, conducted since 2000, it should be noted that the transition of the deepest lake in Poland from oligotrophy to a-mesotrophy occurred in the late twentieth century (Fig. 5A). In the same period, the trophic state of other large SLP lakes remained in relative balance, a good example of which might be Lake Szurpiły (Fig. 5A). Gradually deteriorating optical conditions in the waters of Lake Hańcza have been observed since the thirties of the last century (Fig. 5B). Interannual fluctuations in mean Secchi disc transparency during mid-summer, the causes of which should be sought in the natural fluctuations of climate, are about $3.2 \mathrm{~m}$. The extent of these fluctuations has been relatively stable throughout the last 80 -year period for which measurement data are available. In the same period, following climate and environmental changes in the lake catchment, the mean transparency of the lake water has decreased by about $3.0 \mathrm{~m}$. In the years 19302015 the average decrease in Secchi disc transparency in Lake Hańcza was 0.3-0.4 m per decade.

\section{References}

Abbot M.R., Denman K.L., Powell T.M., Richerson P.J., Richards R.C., Goldman C.R., 1984, Mixing and the dynamics of the deep chlorophyll maximum in Lake tahoe, Limnol. Oceanogr. 29(4): 862-878.

Borowiak D., 2009, Optical classification of lakes in northern Poland, Limnol. Rev. 9(4):141-152.

Borowiak D., 2011, Właściwości optyczne wód jeziornych Pomorza (Optical properties of the Pomeranian lake waters), Wydaw. UG, Gdańsk, 275 pp. (in Polish, English summary).

Borowiak D., 2014, optical properties of Polish lakes: the Secchi disc transparency, Limnol. Rev. 14(3): 131-144.

Borowiak D., Nowiński K., Borowiak M., Grabowska K., 2016, Abiotic environment of lobelia lake ecosystems, [in:] Bociąg K., Borowiak D. (eds), Lobelia lakes in the second decade of the XXI century, Wydaw. UG, Gdańsk: 19-50 (in Polish, English summary).

Camacho A., 2006, On the occurrence and ecological features of deep chlorophyll maxima (DCM) in Spanish stratified lakes, Limnetica 25(1-2): 453-478.

Czeczuga B., Grądzki F., 1970, Primary production in the oligotrophic Lake Hańcza, Ekol. Pol. 18(17): 383-392.

Czeczuga B., 1994, Studies of aquatic fungi. 17.Aquatic fungi of Lake Hancza in the Suwalki Scenic Park and of some adjacent lakes [northeastern Poland], Acta Hydrobiol. 36(3): 371-385.

Davies-Colley R.J., Vant W.M., Smith D.G., 2003, Colour and clarity of natural waters. Science and management of optical water quality, Blackburn Press, Caldwell, 310 pp.

Faraś-Ostrowska B., Lange W., 1998, Przezroczystość wody jako miara nasilenia eutrofizacji jezior (Water transpar- ency as a measure of the intensity of lake eutrophication) [in:] Lange W., Borowiak D. (eds), Zagrożenia degradacyjne a ochrona jezior, Bad. Limnol. 1, KLUG, Gdańsk: 181-191 (in Polish).

Ficek D., 2013, Właściwości biooptyczne wód jezior Pomorza oraz ich porównanie z właściwościami wód innych jezior i Morza Bałtyckiego (Bio-optical properties of waters in Pomeranian lakes and their comparison to optical properties of other lakes waters and the Baltic Sea), Rozpr. Monogr. 23/2013, PAN IO, Sopot, 351 pp. (in Polish, English summary).

Ficek D., Borowiak D., 2016, Właściwości optyczne wód jezior PN "Bory Tucholskie" (Optical properties of lake water in the "Bory Tucholskie" NP), [in:] Choiński A., Kochanowska M., Marszelewski W. (eds), Przyroda abiotyczna Parku Narodowego „Bory Tucholskie” (Abiotic nature in the „Bory Tucholskie” National Park, Bogucki Wyd. Nauk., Poznań: 307-329 (in Polish, English summary).

Górniak A., Szumieluk D., Zielinski P., Suchowolec T., Jekatierynczuk-Rudczyk E., 2007, jeziora Suwalskiego Parku Krajobrazowego - aktualna trofia i jakość wód (Lakes of the Suwałki Landscape Park - current trophy and water quality), Mat. Konf. „Parki krajobrazowe w krajowym systemie ochrony obszarowej”, Szelment 28-29 września 2006, Turtul, 31-36 (in Polish).

Górniak A, Więcko A., Karpowicz M., 2016, Changes in the trophic status of lakes in the Suwałki Landscape Park (NE Poland), Limnol. Rev. 16(4): 221-227.

Howard-Williams C., Vincent W.F., 1984, Optical properties of New Zealand lakes, 1: Attenuation scattering, and a comparision between downwelling and scalar irradiances, Arch. Hydrobiol. 99: 318-330.

Jekatierynczuk-Rudczyk E., Zieliński P., Grabowska M., Ejsmont-Karabin J., Karpowicz M., Więcko A., 2014,The trophic status of Suwałki Landscape Park lakes based on selected parameters (NEPoland), Environ. Monit. Assess. 186(8): 5101-5121.

Kalff J., 2003, Limnology. Inland water ecosystems, Prentice Hall, Upper Saddle River, 592 pp.

Kirk J.T.O., 1996, Light and Photosynthesis in Aquatic Ecosystem, Cambridge University Press, Cambridge, 509 pp.

Koenings J.P., Edmundson J.A., 1991, Secchi disk and photometer estimates of light regimes in Alaskan lakes: Effects of yellow color and turbidity, Limnol. Oceanogr. 36(1): 91-105.

Kondracki J., 1994, Geografia Polski. Mezoregiony fizycznogeograficzne (Physical geography of Poland. Physicogeographical mesoregions), Wydaw. PWN, Warszawa, 340 pp. (in Polish).

Koźmiński Z., 1932, O stosunkach tlenowych w jeziorze Hańcza na Suwalszczyźnie (The oxygen conditions in Lake Hańcza in the Suwałki Region), Arch. Hydrobiol. Ryb. 6: 65-85 (in Polish, German summary).

Lange W., 1986, Fizyczno-limnologiczne uwarunkowania tolerancji systemów jeziornych Pomorza (Physico-lim- 
nological conditioning of the Pomeranian lake systems tolerance), Zesz. Nauk. UG Rozpr. Monogr. 79, Gdańsk, 177 pp. (in Polish, English summary).

Lange W., Maślanka W., Nowiński K., 2003, Physical-limnological manifestations of present transformations of chosen lakes of Suwalskie Lakeland, Limnol. Rev. 3: 135-142.

Mikulski Z., 1973, Badania promieniowania słonecznego $\mathrm{w}$ jeziorach polskich (Studies on the penetration of solar radiation into Polish lakes), Prz. Grofiz. 26(3-4): 291-301 (in Polish, English summary).

Morris D.P., Zagarese H., Williamson C.E., Balseiro E.G., Hargreaves B.R., Modenutti B., Moeller R., Queimalinos C., 1995, The attenuation of solar UV radiation in lakes and the role of dissolved organic carbon, Limnol. Oceanogr. 40(8): 1381-1391.

Reinart A., Harlevi A., Arst H., Sipelgas L., 2003, Preliminary optical classification of lakes and coastal waters in Estonia and south Finland, J. Sea Res. 49(4): 357-366.

Reynolds C.S., 1984, The ecology of freshwater phytoplankton, Cambridge Univ. Press, Cambridge, 384 pp.

Reynolds C.S., 1992, Dynamics, selection and composition of phytoplankton in relation to vertical structure in lakes, Arch. Hydrobiol. 35: 13-31.

Richling A., 1985, Regionalizacja fizycznogeograficzna województwa (Physicogeographical regionalization of the voivodeship), [in:] Stasiak A. ed.) Województwo suwalskie. Studia i materiały. Tom 1. (Suwałki Voivodeship. Studies and materials. Vol. 1), Wyd. OBN w Białymstoku, Białystok: 169-200 (in Polish).

Silsbe G.M., Hecky R.E., Guildford S.J., 2006, Variability of chlorophyll a and photosynthetic parameters in a nutrient-saturated tropical great lake, Limnol. Oceanogr. 51(5): 2052-2063.

Stangenberg M., 1936, Szkic limnologiczny na tle stosunków hydrochemicznych Pojezierza Suwalskiego. Suchar i Jezi- orko jako stadjum przejściowe zanikania jezior (Limnological study against the hydrochemical conditions of the Suwałki Lakeland. Lakes Suchar and Jeziorko as a transitional stage of lake disappearance), Pr. Inst. Bad. Lasów Państw. A 19: 1- 85 (in Polish, German summary).

Stangenberg M., 1937, Charakterystyka limnologiczna jezior grupy Kleszczowickiej i Hańczańskiej na pojezierzu Suwalszczyzny (Limnological characteristics of the Kleszczówek and Hańcza lake groups in the Suwałki Lakeland), Pr. Inst. Bad. Lasów Państw. A 23: 1-17.

Stenz E., Mikulski Z., 1951, Pomiary przenikalności promieniowania słonecznego w jeziorach i ich zastosowanie (Studies on the penetration of solar radiation into lakes and their use), Gosp. Wod. 11(12): 441-451 (in Polish).

Sterner R.W., Elser J.J., Fee E.J., Guilford S.J., Chrzanowski T.H., 1997, The light:nutrient ratio in lakes: The balance of energy and materials affects ecosystem structure and proces, Am. Nat. 150(6): 663-684.

Szczepański A., 1961, Charakterystyka limnologiczna jeziora Hańcza (Limnological characteristic of Hańcza lake), Pol. Arch. Hydrobiol. 9: 9-18 (in Polish).

Talling J.F., 1971, The underwater light climate as a controling factor in the production ecology of freshwater phytoplankton, Mitt. Int. Verein. Limnol. 19: 214-243.

Zdanowski B., Stawecki K., Pyka J.P., 2008, Środowisko abiotyczne jeziora Hańcza (Abiotic environment of Lake Hańcza), [in:] Kozłowski J., Poczyczyński P., Zdanowski B. (red.) Środowisko i ichtiofauna jeziora Hańcza (Environment and ichthyofauna of Lake Hańcza), Wydaw. IRS, Olsztyn: 59-73 (in Polish).

Zieliński P., Kłoczewska A., Górniak A., 2006, Summer bacterioplankton abundance and biomas in lakes of Suwałki Landscape Park, pol. J. Environ. Stud. 15(5): 543-547. 